\title{
ON DEGLACIATION BETWEEN PIEKSÄMÄKI AND PIELAVESI IN CENTRAL FINLAND
}

\author{
GunNar GLÜCKERT
}

\begin{abstract}
Glückert, Gunnar 1974: On deglaciation between Pieksämäki and Pielavesi in central Finland. Bull. Geol. Soc. Finland 46, 43-51.
\end{abstract}

\begin{abstract}
On the basis of four end moraine formations, some of them not known before, the phases of deglaciation between Pieksämäki and Pielavesi in central Finland have been described in this paper. The trend of these end moraines, other transverse formations and radial eskers show that the ice retreated northwestward on quite an even front. The orientation of these end moraines bear witness to small oscillations and stagnations of the ice during general deglaciation. On the map (App. 1) have been marked the end moraines and radial eskers. On the basis of the trend of the end moraines, the general orientation of the retreating ice margin was drawn on the map of deglaciation (Fig. 6). The directions of striae and radial eskers, running quite a right angle to the trend of the retreating ice margin, were also used to determine the stages of deglaciation. Wherever there were no end moraines, the lines of deglaciation were drawn only on the basis of the trend of the radial eskers.
\end{abstract}

Gunnar Glückert, Institute of Quaternary Geology, University of Turku, 20500 Turku 50, Finland.

\section{Introduction}

At the beginning of the last ice age the high upland area of central Finland were covered by the far-advanced continental ice sheet. This ancient glaciated terrain is clearly drumlinized and forms two immense drumlin fields in the areas of Pieksämäki and Keitele (Glückert 1973).

The term »end moraine» has been used for one or several ridge-like accumulations of drift built through the contact of ice along the margin of an active glacier. They may consist of till or various proportions of till and stratified drift. Several ridges transverse to the movement of ice, linear in extent, form four end moraine systems in the study area (Fig. 1).

The purpose of this study was to search for end moraines in the area between Pieksämäki and Pielavesi in central Finland. Four systems of end moraines, consisting of till ridges, transverse eskers and glaciofluvial deposits orientated SW -NE, have been discovered by the present author between Pieksämäki and Piclavesi in central Finland. These formations indicate that the 


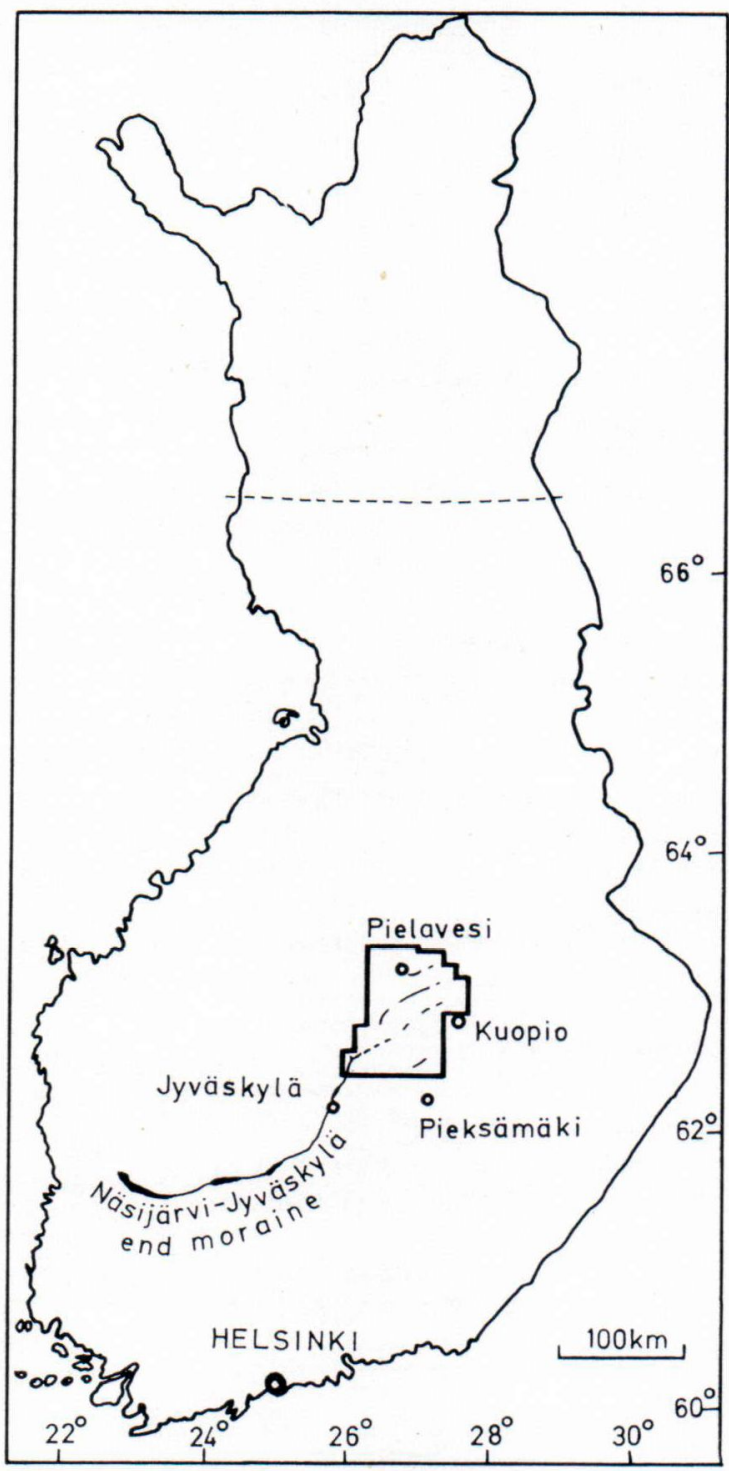

Fig. 1. Study area in central Finland.

edge of the retreating ice sheet had run at a right angle to the orientation of the glacial striae, eskers, and drumlins. In general, end moraines and transverse eskers indicate the position of the ice margin.

In the area between these four end moraines no clear sings of activity by the ice margin were found. Numerous discontinuous radial esker systems indicate that the ice retreated along a fairly even front through the area. According to Sauramo's (1923) recession lines the ice retreated towards the NW.

Preliminary investigations were carried out by studying topographical maps $1: 20000$, on which all end moraines and other possible ice marginal deposits were located. This information was checked in the field in July 1973, where the directions of glacial striae were measured, and the morphology and inner structure of the end moraines and eskers were studied. In many areas there are very few road cuttings and gravel pits in the end moraines, and for this reason no clear picture of their structure and genesis could be obtained. Therefore it cannot always be proved whether we have a radial esker or an end moraine ridge. For this reason the terms transverse or ice marginal formation, are used in this paper also for separate ridges of the end moraine systems.

The greatest end moraine formation of central Finland, called the Näsijärvi-Jyväskylä end moraine, is situated southwest of the area being studied here. This end moraine was investigated for example by Leiviskä (1951), Repo (1964) and Aartolahti (1972). In the present author's opinion this ice marginal formation seems to continue in the areas of Tankolampi, Istunmäki, Kerkonkoski and Itä-Karttula between Suonenjoki and Pielavesi.

Three other end moraine systems, with a broken row of several ridges, linear in extent, were discovered in the area between Pieksämäki and Pielavesi. The most important end moraine systems in the study area are the following:

- the Kourujärvi end moraine ( $\mathrm{I}$ in App. 1),

- the Tankolampi-Istunmäki and Itä-Karttula end moraines (II),

- the Vesanto and Koivulahti-Pulkonkoski end moraines (III), and

- the Pielavesi end moraine (IV).

In the area between Pankajärvi and Jylänki some short transverse ridges were observed. Brander (1934) has published a geological map 
of Quarternary deposits (with an explanation) of central Finland west of the town of Kuopio. He mentiones some end moraines, lying at Pielavesi and Kourujärvi, but has not studied them closer.

The stages of deglaciation in southern and western Finland have earlier been described by Sauramo (e.g. 1923, 1940), Brenner (1945), Virkkala $(1960,1963)$, and M. Okko (1962). Recently Aartolahti (1972) has studied the deglaciation in the light of the evidence provided by end moraines. By means of joining together the end moraines running in the same direction, he was able to draw lines on his maps indicating separate sites of the ice margin and thus stages of deglaciation.

The method used by Aartolahti (1972) has been followed in this study. The lines of deglaciation (Fig. 6) were drawn on the basis of the end moraines, and the orientation of the striae, drumlins and radial eskers. If there were no end moraines, the lines of deglaciation were drawn only on the basis of the run of radial eskers. In general, the ice margin retreated northwestwards, and the direction of advance had been roughly southeast. The end moraine systems in the study area bear evidence of some slight advances or stagnation of the ice during deglaciation.

\section{Striae}

In general, the main exaration on the bedrock originated in the time of the glacial advance. A great deal of striation was also formed by slight local (annual) advances of the ice during general deglaciation.

In the area of Suonenjoki the main trend of striation indicates southeastward movement of the ice. Just west of the Näsijärvi-Jyväskylä end moraine, SE of Suolahti, the striae show an advance by an active glacier coming from the W-WNW $\left(280^{\circ}\right)$. Just east of the formation the orientation of the striae is towards the $S$ and SSE (App. 1).
Between Tankolampi and Konnevesi, the movement of the ice indicates a flow towards the SE-SSE. In the area of Keitele the ice had advanced from the W; the trend of retreat, however was to the NW, as indicated by the radial eskers. In the area of the Pielavesi end moraine the margin of the ice first retreated towards the NW - WNW $\left(285-300^{\circ}\right)$, followed by an advance to the SSE as proved by the striae measurements $\left(320^{\circ}\right)$ (App. 1).

\section{End moraine systems}

\section{The Kourujärvi end moraine (I)}

The Kourujärvi end moraine lies SW of the market town Suonenjoki. This ice marginal formation is built up of some transverse ridges and glaciofluvial deposits lying in a deep transverse fracture valley at Kourujärvi, on both sides of the Rautalampi-Ahveninen radial esker system. The road connecting the towns Jyväskylä and Kuopio runs along this valley. Some road cuttings and gravel pits show that this formation is composed partly of till, and partly of more or less stratified drift.

The retreating margin of the inland ice did not make an advance at Kourujärvi, but a slight stagnation was enough to deposit these small ice marginal formations along this deep valley.

\section{The Tankolampi-Istunmäki and Itä-Karttula end moraines (II)}

The Tankolampi-Istunmäki end moraine system is built up of many isolated moraine ridges and more or less sorted deposits, running in 23 parallel rows between Tankolampi, Istunmäki and Kerkonkoski. This broken system continues NW of Karttula, where it forms a few end moraines and transverse glaciofluvial ridges (Fig. 3 and App. 1).

The Itä-Karttula end moraine system, $2.5 \mathrm{~km}$ long, $100-500 \mathrm{~m}$ wide, lies $\mathrm{NE}$ of 
Itä-Karttula and runs along the shores of Lake Salminen. This end moraine has a few small, narrow, low end moraine ridges, which together are surrounded by wide, flat fields of sand and gravel.

On the northern shore of Lake Salminen runs a ridge with steep slopes, $2-3 \mathrm{~m}$ high and $20 \mathrm{~m}$ wide. It is covered by $1-2 \mathrm{~m}$ of slightly sorted till-like drift, rich in boulders. The core of the ridge is composed of better sorted sand and gravel without any clear stratified structure. The base of the ridge consists of hard greyish ground moraine. At Paloniemi, on the other side of the lake, there rises a $6-8 \mathrm{~m}$ high ridge composed of glaciofluvial sand and gravel. However, its core is of coarse-grained till. This ridge runs to the NE and forms later $1-2$ parallel end moraine ridges at Lintulankangas. These ridges are composed of till, rich in boulders, with flat slopes of fine sand deposits (Fig. 2).
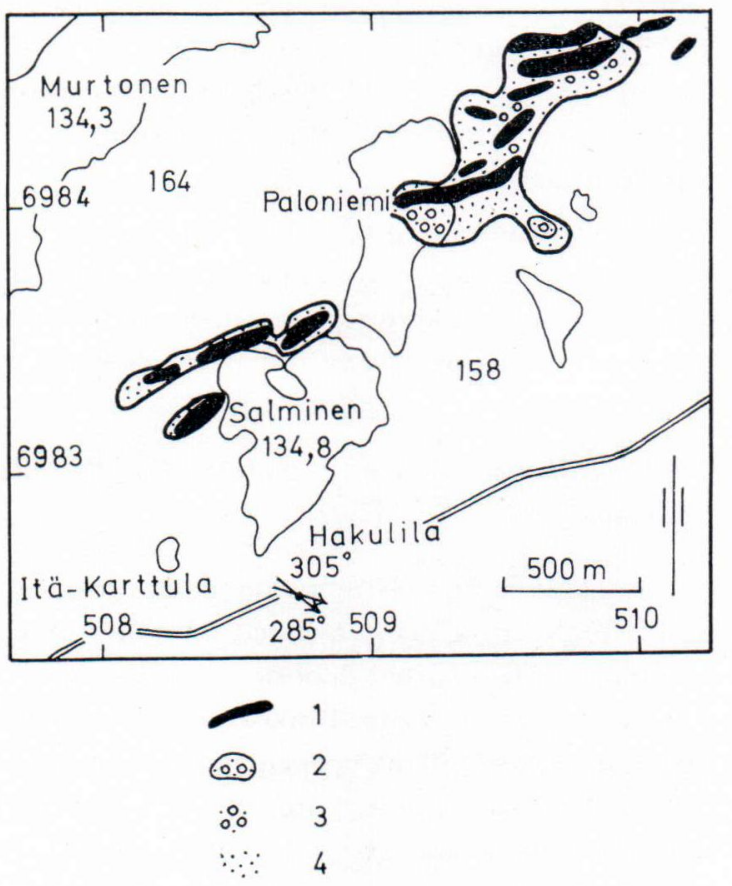

Fig. 2. The Itä-Karttula end moraine seems to be a continuation of the Tankolampi-Istunmäki and Näsijärvi-Jyväskylä end moraine systems (II in Appendix 1).
The Vesanto and Koivulabti-Pulkonkoski end moraine systems (III)

The longest and best developed end moraine system in the study area runs from Kuuslahti to Vesanto, and continues behind Lake Niinivesi from Koivulahti via Kiukoonaho and Kankainen to Pulkonkoski, in the vicinity of Lake YläPulkko. The length of the Vesanto transverse formation is about $10 \mathrm{~km}$, that of the Koivulahti-Pulkonkoski one $30 \mathrm{~km}$.

The ridges of these end moraines are lined up in a row, consisting mostly of quite well-sorted stratified drift, but sometimes also of till. According to their shape, material and construction, these end moraines must be regarded partly as transverse eskers, and partly as end moraines. Some parts of the transverse formations are built up of low sand fields, without any special shape of ridge.

The $\mathrm{V}$ es anto transverse system runs between Kuuslahti, Lake Pohjainvesi and the village of Vesanto, west of Lake Niinivesi. This formation resembles an esker ridge, beeing $10 \mathrm{~km}$ long and $2-10 \mathrm{~m}$ high, composed mostly of stratified sand and gravel. On both sides of the ridge there have been deposited extensive sand fields. At Kuuslahti, the Vesanto formation turns to the $\mathrm{S}$, where it connects with the radial esker system of Rautalampi-Ahveninen, west of Vesanto.

SW of the church of Vesanto the formation consists of a low ridge composed of poorly sorted till-like sand and gravel, rich in boulders on the surface. SW of the river between Lakes of Keski- and Ylä-Asuinjärvi, the formation becames wider and higher. At Vetokangas it forms a 5-10 $\mathrm{m}$ high transverse ridge, surrounded by wide sand deposits. The ridge of Syrjänkangas, $10 \mathrm{~m}$ high and $100 \mathrm{~m}$ wide, consists of a glaciofluvial core of stratified sand and gravel, covered with fine sand deposits.

The observations on striae indicate that the Vesanto formation can be regarded as an end moraine system. It resembles a transverse esker, 


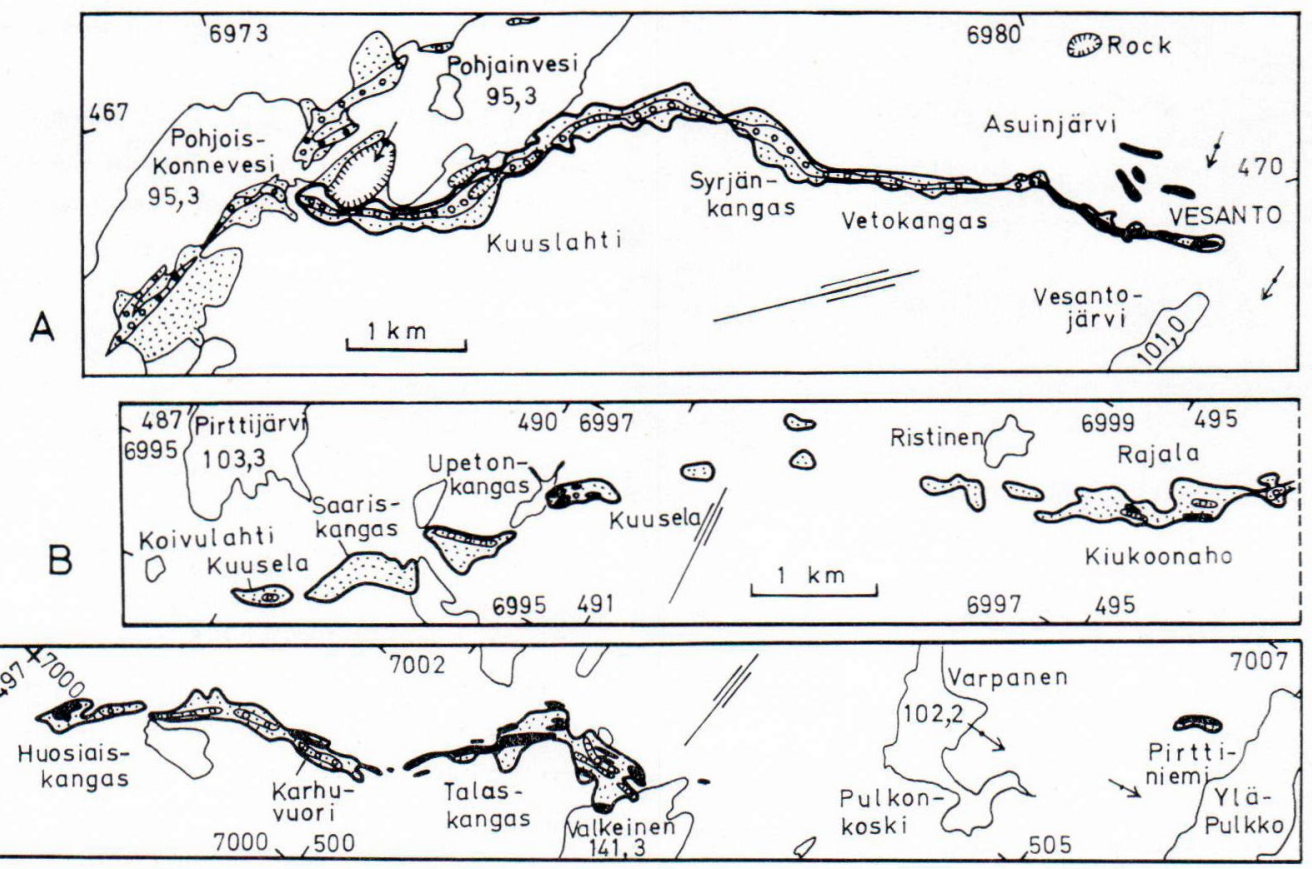

Fig. 3. The Vesanto (A) and Koivulahti-Pulkonkoski (B-C) end moraines (III in Appendix 1).

deposited in a broad crack along the margin of the retreated, melting ice. At the south end of Lake Pohjainvesi the striae show a northwesterly direction $\left(315^{\circ}\right)$. At Vesanto the striae lie between 300 and $325^{\circ}$. According to Brander (1934 p. 29) this formation is an esker. (Fig. 3).

The end moraine system of Vesanto has its continuation NE of Lake Niinivesi. At Kuusela, the Koivulahti-Pulkonkoski formation begins as a small sandy deposit and overlies the greyish ground moraine as a $2 \mathrm{~m}$ thick layer.

The Saariskangas ridge is, a sand field 300$400 \mathrm{~m}$ wide and $5 \mathrm{~m}$ high. S of the Upetonkangas formation lies a wide sandy deposit. At its northern end a higher transverse sand and gravel ridge runs from $\mathrm{W}$ to E. At Kuusela, NE of Lake Likaslampi, deposits of poorly sorted morainic material and some low blocky moraine ridges can be found. In the area of Ristinen, several low sandy formations have been deposited. At Rajala the main transverse ridge is surrounded by low sand fields and few moraine ridges.
At Pirttipuro, near Kiukoonaho, the material of the end moraine ridges consists of poorly sorted sandy till. North of the Huosiaiskangas ridge run a discontinuous sand and gravel ridge and beyond it an end moraine ridge, surrounded by bogs.

The Seiväsmäki transverse formation becomes narrover near Lake Huosiaistenjärvi. W of the Laihasuo bog the $20 \mathrm{~m}$ high transverse ridge of Karhuvuori rises with $40^{\circ}$ steep slopes, rich in boulders. The formation goes on through the Laihasuo bog in the form of low sandy deposits. At Talaskangas a $3-5 \mathrm{~m}$ high ridge consists of sandy till, rich in blocks and stones (Fig. 4).

In the area of Kankainen, E of Lake Valkeisenjärvi, the end moraine is very prominent. It forms several short end moraine and transverse esker ridges, 5-10 $\mathrm{m}$ high, with steep slopes and rich in boulders on the surface. This ridge area is surrounded by large sandy plains.

Near Pirttiniemi on the shore of Lake YläPulkko, a 3-6 $\mathrm{m}$ high end moraine ridge, be- 


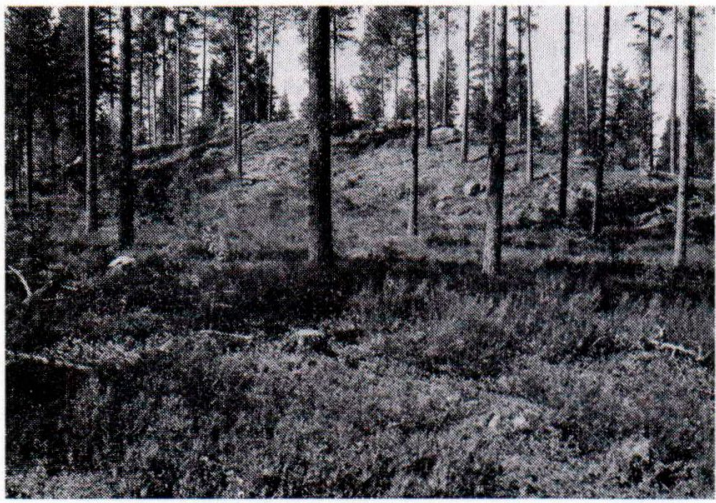

Fig. 4. A $10 \mathrm{~m}$ high transverse esker with steep slopes rich in blocks on the surface, near Valkeinen, belongs to the Koivulahti-Pulkonkoski end moraine system.

Photo Glückert 6. 7. 73.

longing to the same formation, can be found. Its core is built up of till, rich in blocks, and covered with sandy slopes.

\section{The Pielavesi end moraine ( $I V$ )}

The Pie 1 a vesi end moraine system consists of two large transverse glaciofluvial deposits forming the formations of Pukarankangas and Karhukangas several $\mathrm{km}$ east of Pielavesi. East of the Pukarankangas formation there are few small end moraine ridges belonging to the same system (Fig. 5).
The transverse formation of Pukarankangas is about $2 \mathrm{~km}$ long, $1 \mathrm{~km}$ wide and $40 \mathrm{kmi}$ high, rising up to $155 \mathrm{~m}$ above sea level at Pajuskylä. At its northeastern end the ridge becames narrow and splits into $2-3$ parallel end moraines, consisting of poorly sorted coarse-grained material and till. The core of Pukarankangas ridge is composed of washed coarse sand and gravel, rich in blocks and stones. A slight mantle of till on the proximal slope proves that the end moraine has been formed at the ice margin, following a small advance of ice from the NW. The character of an end moraine can also be seen from the striation, running south of the formation from the W-WNW $\left(270-285^{\circ}\right)$ and just north of it from NW $\left(320-330^{\circ}\right)$ (Fig. 5, App. 1).

The Pukarankangas end moraine is connected to the Pajumäki-Harjakangas longitudinal esker system that begins at the NW end of this transverse formation. East of the big drumlins at Löytynmäki the long esker of Orikangas, belonging to the Maaninka-Korpijärvi radial esker system, runs from SE to NW (Fig. 5).

The Karhukangas end moraine, connected with the Honkamäki radial esker, is a $40 \mathrm{~m}$ high ridge. Honkamäki is the beginning of the Pielavesi-Kirkkosaari esker. Between Arkkuvuori (182.2) and Honkamäki, Karhukangas seems to be a flat-topped deltaic formation, $173 \mathrm{~m}$ high. At its distal edge there runs a till ridge, rich in

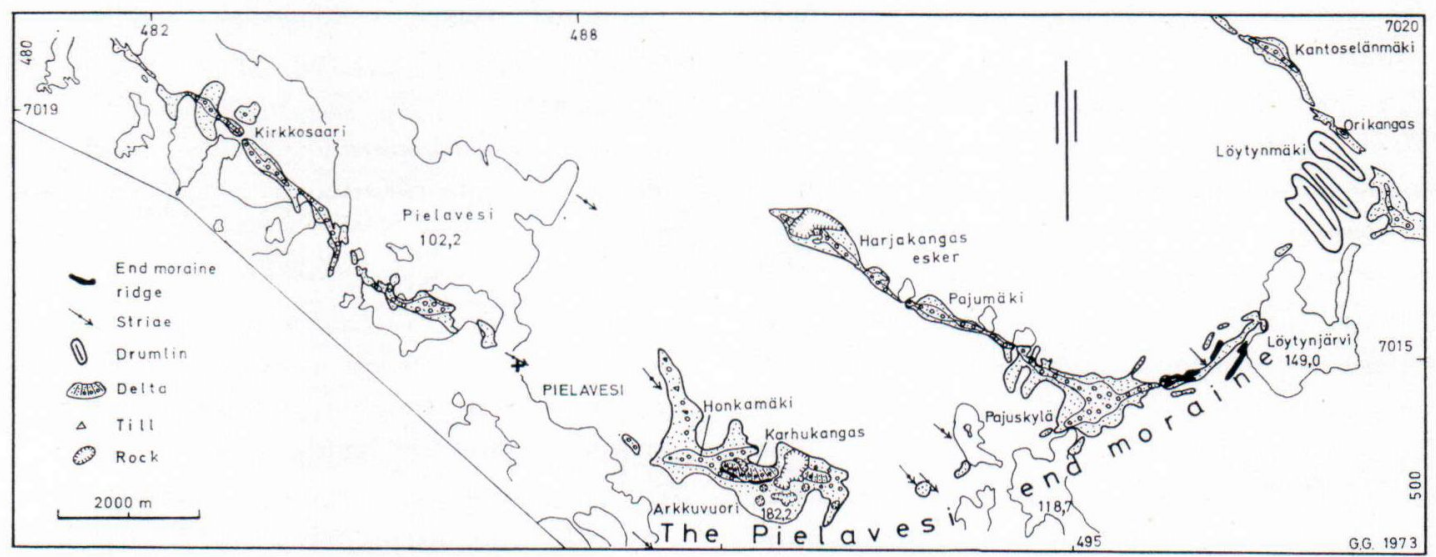

Fig. 5. The Pielavesi end moraine (IV). 
blocks, to be explained as an end moraine at the summit of the plain (Fig. 5). Outcrops of bedrock are exposed at Arkkuvuori and Karhukangas. Honkamäki (173), the western part of the formation, consist of stratified gravel and sand, and is regarded as an esker. No clear picture of the structure of Karhukangas has been obtained, for it has no new gravel pits or road cuttings.

The Pielavesi end moraine, formed of Karhukangas and Pukarankangas, has the character of an end moraine because of its trend of orientation to the supposed direction of the ancient ice margin. This hypothesis has also been proposed by Brander (1934).

\section{Radial eskers}

Parts of several broken radial esker systems run across the study area (App. 1). The most dominant eskers are the following:

- the Siilinjärvi esker, which branches into two parts, the Maaninka-Korpijärvi esker and Lapinlahti-Iisalmi esker.

- two eskers, beginning near Pielavesi, the Honkamäki-Kirkkosaari-Pyhäjärvi esker and the Pajumäki-Harjakangas esker,

- the Karttula-Tervo-Keitele esker,

- the Suonenjoki-Vesanto esker,

- the Rautalampi-Ahveninen esker,

- the Konnevesi esker and

- the Lievestuore-Sumiainen esker.

The run and structure of these esker systems are described in more detail by Brander (1934). However, he regards the Pielavesi-Pyhäjärvi esker as a continuation of the Siilinjärvi-Maaninka esker system.

\section{Deglaciation}

The stages of deglaciation in central Finland were investigated on the basis of end moraines, striae and radial eskers. These glacial elements indicate that the ice retreated northwestwards on quite an even front. The end moraines and variations in the trend of striation bear witness to some small oscillations, stagnations and advances by the ice during general deglaciation (Fig. 6).

The great drumlin field in the area of Pieksämäki and Juva, central Finland, lies on a high upland watercourse plateau (Glückert 1973). In the northern parts of this drumlin field, in the vicinity of Pieksämäki, south of the area now studied, no end moraines were discovered. The margin of the ice seems to have retreated quite rapidly northwestwards, without any signs of halts.

At Kourujärvi, SW of Suonenjoki, the ice margin stagnated, and small transverse ridges and deposits consisting of till and poorly washed drift were formed along a deep fracture valley of the bedrock. This fracture zone may have caused a slight stagnation of the retreating ice along this valley.

Between Tankolampi, Konnevesi, Istunmäki and Kerkonkoski, several broken parallel ridges of end moraines and other transverse deposits provide evidence of some slight halts by the retreating ice margin. These end moraines seem to be the continuation of the great end moraine of central Finland, the Näsijärvi-Jyväskylä end moraine. The short Itä-Karttula end moraine W of Kuopio belongs to the same system as the Tankolampi-Istunmäki end moraine.

The Vesanto end moraine seems to be a transverse ice marginal formation, running not quite at a right angle to the trend of the radial eskers, striae and thus of the general deglaciation. The long Koivulahti-Pulkonkoski end moraine, on the other side of Lake Niinivesi, belongs to the same phase of deglaciation.

After having retreating slightly northwestwards of Pielavesi, the ice became active, advancing in a small lobe to the SSE, and deposited the Pielavesi end moraine along the edge of the glacier. After this advance the ice again retreated back towards the NW. 


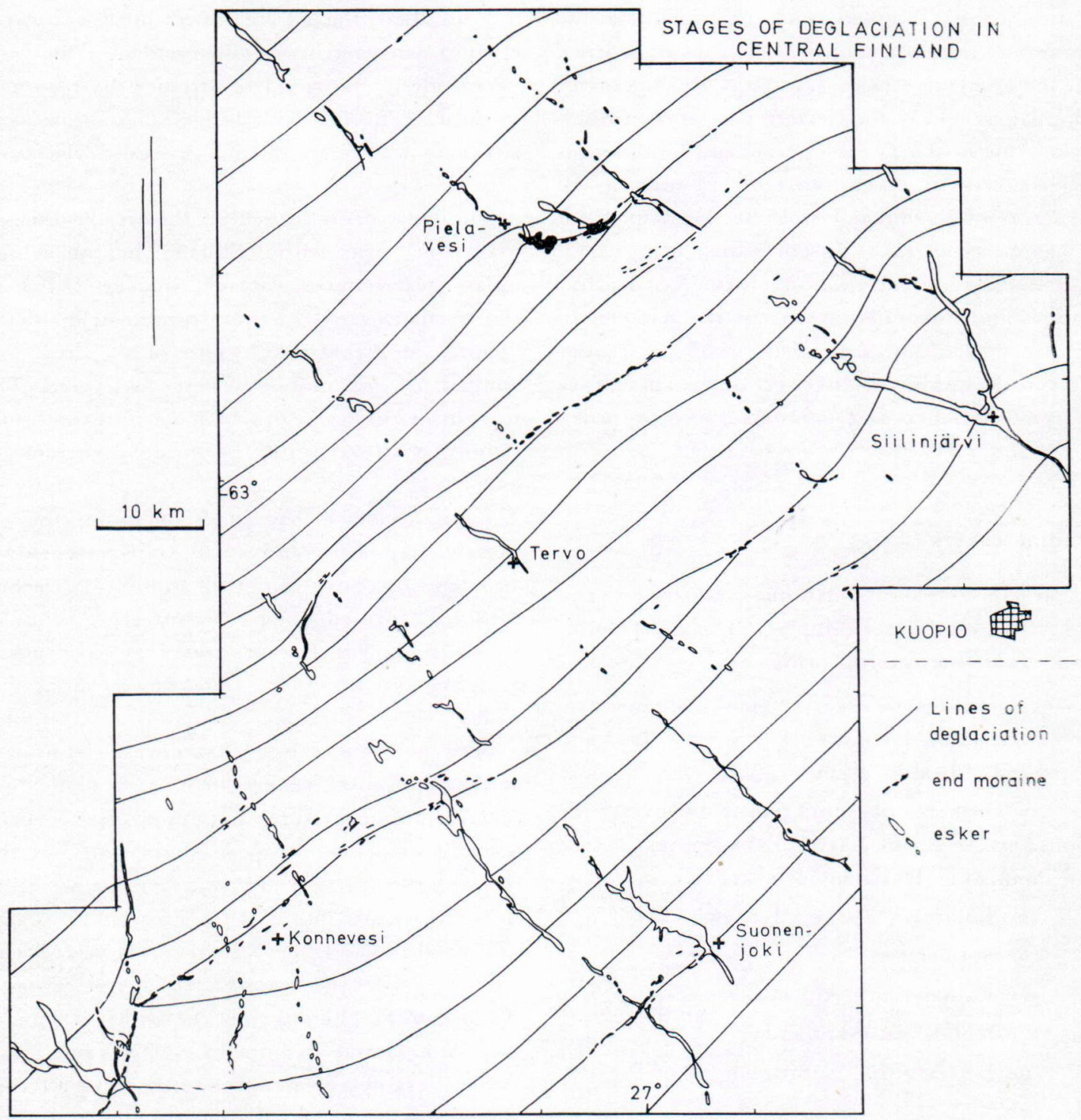

Fig. 6. Stages of deglaciation in central Finland.

At Siilinjärvi the radial esker branches into two great parts. The westerly one runs via Maaninka, and is perhaps older than the other branch, the Lapinlahti-Iisalmi esker. The latter lies on the border between two melting ice masses retreating in two different directions. That can be seen from the different orientation of radial eskers in the area north of Siilinjärvi.

\section{REFERENCES}

Aartolahtr, Torve (1972) On deglaciation in southern and western Finland. Fennia 114, 84 p.

Brander, G. (1934) Suomen geologinen yleiskartta. Lehti C 3, Kuopio. Maalajikartan selitys. Suomen geologinen toimikunta, $67 \mathrm{p}$.

Brenner, ThORD (1945) Finlands åsars vittnesbörd om ytgestaltningen hos landisen. Fennia 68, 39 p. 
Glückert, Gunnar (1973) Two large drumlin fields in central Finland. Fennia 120, 37 p.

LeIVISKä, IrVARI (1951) Drei eiszeitliche Randmoränen. Fennia 74, 1, 83 p.

Oкко, Marjatta (1962) On the development of the first Salpausselkä, west of Lahti. Bulletin de la Commission géologique de Finlande 202, 162 p.

Repo, Reino (1964) Observations on the Jyväskylä icemarginal formation in central Finland. Bulletin de la Commission géologique de Finlande 215, pp $147-162$.
Sauramo, Matti (1923) Studies on the Quaternary varve sediments in southern Finland. Fennia 44, 1, 164 p.

- (1940) Suomen luonnon kehitys jääkaudesta nykyaikaan. Porvoo-Helsinki, 286 p.

VirkKala, Kalevi (1960) On the striation and glacier movements in the Tampere region, southern Finland. Bulletin de la Commission géologique de Finlande 188, pp 159-176.

- (1963) On the ice-marginal features on southwestern Finland. Bulletin de la Commission géologique de Finlande 210, 76 p.

Manuscript received, October 15, 1973. 